\title{
ARE THE ELDERLY REALLY \\ OVER-ANNUITIZED? \\ NEW EVIDENCE ON LIFE INSURANCE \\ AND BEQUESTS
}

Jeffrey R. Brown

Working Paper 7193

http://www.nber.org/papers/w7193

\author{
NATIONAL BUREAU OF ECONOMIC RESEARCH \\ 1050 Massachusetts Avenue \\ Cambridge, MA 02138 \\ June 1999
}

For helpful comments and discussions, I wish to thank Anne Case, Courtney Coile, Peter Diamond, Jon Gruber, Jerry Hausman, Jim Poterba, Harvey Rosen, Scott Weisbenner, participants in the MIT Public Finance lunch, and participants in the NBER Aging Conference. The author gratefully acknowledges the financial support of the NBER and NIA Aging Fellowship and the National Science Foundation. All opinions expressed are those of the authors and not those of the National Bureau of Economic Research.

(C) 1999 by Jeffrey R. Brown. All rights reserved. Short sections of text, not to exceed two paragraphs, may be quoted without explicit permission provided that full credit, including $\subseteq$ notice, is given to the source. 
Are the Elderly Really Over-Annuitized?

New Evidence on Life Insurance and Bequests

Jeffrey R. Brown

NBER Working Paper No. 7193

June 1999

JEL No. J14, H55

\section{ABSTRACT}

This paper provides evidence against the hypothesis that elderly individuals with strong bequest motives purchase term life insurance to offset mandatory annuitization by the existing Social Security system. Using new data on elderly households, this study is able to examine ownership of pure term life insurance separately from whole life, or cash-value, policies. This is an important distinction in the "Annuity Offset Model" because the central implication is that term insurance is purchased in order to "undo" excessive government annuitization in the form of Social Security, while whole life policies among the elderly primarily consist of tax deferred savings. Evidence is presented that many households simultaneously choose to hold privately purchased annuities and term life insurance, a choice that is inconsistent with the notion that these individuals are overannuitized. Results also indicate that the hypothesized positive relationship between term insurance ownership and Social Security benefits does not hold once one analyzes term separately from cash value policies. Previous empirical results appear to have been overly favorable to the Annuity Offset Model due to the inability to adequately account for the strong correlation between whole life insurance ownership and Social Security benefits, a correlation that can be attributed to tax-deferred savings and attempts to protect human capital during one's younger working life. Because these findings suggest that households are not seeking to "undo" Social Security for bequest reasons, these results have implications for the current debate over annuitization options in an individual accounts retirement system.

Jeffrey R. Brown

Kennedy School of Government

Harvard University

79 John F. Kennedy St.

Cambridge, MA 02138

and NBER

brown@nber.org 


\section{INTRODUCTION}

It is well established in the economics literature that annuities ought to be of substantial value to life-cycle consumers who face an uncertain date of death. Yaari (1965) proved that a life-cycle consumer with an uncertain lifetime and no bequest motives would find $100 \%$ annuitization the optimal investment. More recent work has quantified the potential utility gains to such a life cycle consumer. For example, a 65 year old male life cycle consumer would be willing to give up nearly one-third of his wealth to gain access to an actuarially fair market for annuities (Mitchell, Poterba, Warshawsky \& Brown, 1999).

Buying a life insurance contract is analogous to selling an annuity. Life insurance is generally viewed as an appropriate product for working age individuals who seek to protect their family against the loss of future labor earnings (Lewis, 1989). However, it appears to serve little purpose in the portfolio of a retired life-cycle consumer who is concerned only with self-financing retirement out of his or her accumulated wealth. With no labor earnings to insure, an elderly individual should be purchasing annuities in order to provide a certain consumption stream in retirement, not selling annuities through the purchase of life insurance. Even if the individual wishes to leave a portion of wealth to his or her heirs in the form of gifts or bequests, this can be achieved by investing this portion of wealth in ordinary bonds or other non-annuitized assets. In fact, if life insurance premiums were higher than actuarially fair, holding riskless bonds would strictly dominate life insurance as a form of wealth transfer.

Yet elderly households in the United States overwhelmingly hold life insurance, while only a small fraction hold privately purchased annuity contracts. In the AHEAD survey, which consists of households age $70+$, privately purchased annuity contracts (excluding private pensions) are held by fewer than $8 \%$ of couples, while $78 \%$ of age $70+$ couples own a life insurance policy on at least one 
member. According to the Life Insurance Ownership study (LIMRA, 1992), ownership of individual (non-group) life insurance policies is actually higher among the age 65+ group than any other age cohort. While this difference is offset by much lower coverage by group (usually employer-based) policies, the overall incidence of coverage among the elderly is quite high by any measure.

Two major alternative hypotheses have been explored in the literature to explain the patterns of life insurance coverage among the elderly. Auerbach \& Kotlikoff $(1987,1989)$ explored the idea that married couples were using life insurance to reallocate annuity streams across survival states of the couple. However, they found virtually no support for the notion that older households were using life insurance to protect potential widows against severe drops in living standards upon the death of the other spouse.

The second hypothesis, suggested by Bernheim (1991), is that life insurance is being held by elderly households to offset an excessive level of mandated annuitization in the form of Social Security. He estimates that $25 \%$ of elderly households have too much of their wealth annuitized and that they are using term life insurance to sell these annuities in order to leave a bequest. To the extent that this "annuity offset model" is true, it has at least two important implications. First, this would be indicative of very strong bequest motives, which is an issue of perennial controversy in the economics literature (e.g., Kotlikoff \& Summers 1981, Modigliani 1988, Hurd 1987, Laitner \& Juster 1996). Second, if individuals are over-annuitized due to these strong bequest motives, this would indicate a potential welfare gain from lessening the extent of the extent of mandated annuitization. This is potentially important in the debate about whether individuals would be required to annuitize individual account accumulations as part of a reformed Social Security system. 
If a significant fraction of households are over-annuitized, allowing individuals some discretion over the disposition of the assets in their individual account could be welfare enhancing.

This paper re-examines the annuity offset model using more recent and better data than was available for the original empirical tests. The four empirical implications of the model that this paper tests are: (i) no individual would hold both term life insurance and private annuities, (ii) the level of Social Security benefits and term life insurance ownership should be negatively correlated, (iii) term life insurance should behave as an inferior good because it is a negative annuity and annuities are normal goods, and (iv) individuals who hold term life insurance must have a Social Security benefit in excess of desired retirement consumption. These implications will be explained in more detail in the next section. This paper presents results that are inconsistent with all four of these empirical implications, and thus concludes that life insurance coverage is not a good indicator of the extent of over-annuitization.

This paper proceeds as follows: Section 1 summarizes the annuity offset model as posited by Bernheim (1991), and outlines the empirical implications of the model to be tested. Section 2 presents and critiques the empirical results from the previous literature, with particular attention on the distinction between types of life insurance. Section 3 discusses the data used in this paper, from the AHEAD study. Section 4 presents empirical results. Section 5 discusses some alternative explanations for life insurance holdings among the elderly. Section 6 concludes.

\section{The Annuity Offset Model of Life Insurance Demand}

The basic insight behind of the annuity offset model of life insurance demand is that individuals can purchase term life insurance in order to sell a government-mandated annuity. Bernheim suggests a simple two-period model that demonstrates this point. Assume that an individual 
possesses total wealth $\mathrm{W}_{0}$, which he is able to divide between two types of investments. It is assumed that the investment decision is taking place after consumption in period 0 has already occurred. The first type of asset, A, is a life contingent annuity contract which yields a return of $\alpha$ in period 1 if the individual is alive, and $\$ 0$ otherwise. The second type of asset, $\mathrm{B}$, is a traditional (bequeathable) financial asset which yields a return of $\beta$ in period 1 regardless of whether the individual is alive or not. If the individual lives, his period 1 resources are $\mathrm{W}_{1}=\alpha \mathrm{A}+\beta \mathrm{B}$. If he dies, his heirs receive $\beta \mathrm{B}$. Because actuarially fair annuities pay a "mortality premium" equal to the probability of dying, $\alpha>\beta$. Utility of the individual is assumed to be a function of total resources and bequeathable resources in period $1, \mathrm{U}=\mathrm{U}\left(\mathrm{B}, \mathrm{W}_{1}\right)$. Call $\mathrm{A}^{*}$ and $\mathrm{B} *$ the quantities of the two assets that correspond to the optimal division of total wealth, subject to the constraint that $\mathrm{W}_{0}=$ $\mathrm{A}+\mathrm{B}$.

Now suppose the government confiscates $\mathrm{A}^{\mathrm{g}}$ in period 0 and returns $\alpha \mathrm{A}^{\mathrm{g}}$ in period 1 , conditional on the individual's survival. In other words, the government mandates a minimum level of annuitization. If $\mathrm{A}^{\mathrm{g}}<\mathrm{A}^{*}$, then the individual simply decreases his private purchase of annuities by an amount equal to $\mathrm{A}^{\mathrm{g}}$, or alternatively, he buys private annuities in the amount of $\mathrm{A}^{*}-\mathrm{A}^{\mathrm{g}}$. If $\mathrm{A}^{\mathrm{g}}>\mathrm{A}^{*}$, then the individual wishes to sell annuities. This can be done through the purchase of a term life insurance contract. When markets for annuities and life insurance are actuarially fair, then the government mandate has no effect on the individual's division of wealth between A and B. Private insurance contracts offset the government annuity dollar-for-dollar. If insurance is not actuarially fair, then the offset is less than dollar-for-dollar, but the basic story is unchanged. Individuals who wish to hold more annuities than the government mandates will own private annuity contracts. Individuals who wish to hold less in annuities will own private life insurance contracts. No individual will hold both private annuities and life insurance, since they are offsetting 
transactions, each with a positive load factor. Some individuals will hold neither, if $\mathrm{A}^{\mathrm{g}}$ is sufficiently close to $\mathrm{A}^{*}$.

There are four major empirical implications that must hold if the annuity offset model is the reason that the elderly hold life insurance. These are:

(1) No individual will hold both private annuities and private term life insurance contracts. Given the existence of significant load factors in annuity markets (Mitchell et. al., 1999), no one would rationally purchase annuities above the actuarial cost only to sell them back below the actuarial cost.

(2) An increase in the level of the mandated annuity will increase the demand for term life insurance. Recall that an individual will hold term life insurance in the amount of $\max \{0$, $\mathrm{A}^{\mathrm{g}}-\mathrm{A}^{*}$. Holding $\mathrm{W}_{0}$ fixed, an increase in $\mathrm{A}^{\mathrm{g}}$ will increase the total amount of life insurance coverage among those who already hold it. It will also cause some individuals who did not hold life insurance before to purchase it.

(3) Term life insurance will behave as an inferior good. If $\mathrm{B}$ and $\mathrm{W}_{1}$ are normal goods, then an increase in the individual's total resources will increase the demand for annuities. This is because a person with more resources will wish to buy more annuities in order to increase retirement consumption. Since term life insurance is a negative annuity, an increase in the demand for annuities corresponds to a decrease in the demand for term life insurance. Therefore, term life insurance will decline with total resources, and thus behave as an inferior good.

(4) The Social Security annuity income flow must exceed consumption. If an individual is over-annuitized due to bequest motives, it must be because his desired consumption is less than the annuity income from Social Security. So long as optimal consumption exceeds the 
level of the Social Security benefit, there is no need to offset Social Security. Rather, one would want to supplement Social Security through the purchase of private annuities. An equivalent way to state this implication is that an individual who purchase life insurance to offset an annuity will not consume out of their non-Social Security resources. They will save these resources for bequests, and will in fact supplement this bequest with the term life insurance.

It should be noted that there are reasons an individual might be "over-annuitized" that have nothing to do with bequest motives. Hurd (1987) points out that when an individual's optimal consumption path is constrained by an exogenously given annuity stream, they may be willing to give up annuitization at an actuarially fair rate in order to loosen this "liquidity constraint." This is especially likely if the individual has little non-annuitized wealth. However, over-annuitization in this case is driven by a desire to re-allocate consumption across one's lifetime, not to re-allocate between consumption and bequests. Another example is the case in which an individual wishes to hold a buffer stock of assets to cover unforeseen expenditure shocks (e.g., health expenditures). In such a situation, they may wish to hold some of their wealth in a non-annuitized form. Once again, the role of the non-annuitized wealth in this case is still to provide for own consumption, not to leave a bequest to one's heirs. In this case, the way to "undo" the excessive annuitization, however, is not to purchase life insurance, since these proceeds will be unavailable for future consumption. Rather, the individual would wish to purchase insurance against the risky future event (e.g., health insurance) or alter their savings behavior in order to provide for a buffer stock. The tests that I propose in this paper are meant to test for over-annuitization that derives from bequest motives, not these other factors. 


\section{Discussion of Previous Empirical Results \& Data Contamination}

Bernheim tested the first three implications of the annuity offset model using the 1975 crosssection of the Retirement History Survey (RHS), and found support for two of them. The most robust finding was that higher Social Security benefits were correlated both with a higher probability of owning life insurance, and with the amount of coverage conditional on owning a policy. His interpretation of this finding is that individuals are using the life insurance to offset excessive levels of Social Security. He also found some evidence to suggest that life insurance coverage was a decreasing function of lifetime resources, which is consistent with the "inferior good" implication, though this finding was not robust across specifications.

The first implication, that no person would hold both life insurance and annuities, was clearly at odds with the data, as $36 \%$ of the RHS sample reported both in-force life insurance holdings and the receipt of pension annuities. He attributes this latter result to data contamination, namely the fact that there is no way in the RHS to distinguish whole from term life insurance. Because much of Bernheim's analysis was focused on trying to overcome this data handicap, it is useful to discuss the relevance of the life insurance typology in more detail.

\subsection{Term Versus Whole Life Insurance}

The distinction between term and whole life insurance is quite important to the annuity offset model. The difference between the two policy types is quite simple, but has important economic implications. Term life insurance contracts provide insurance protection for a specified limited period. The face amount of the policy is payable to the beneficiaries only if the insured dies within the term specified. Common term periods include 1-year, 5-year, 10-year, and 20-year. Most term policies have options allowing an individual to guarantee renewability at the end of the term specified. This means that an individual is not at risk for losing coverage if she is diagnosed with a 
serious health problem, so long as she pays the contract premium. Because the price of a term insurance contract is a function of the probability of the individual dying during that term, premiums are an increasing function of the insured's age.

Whole life policies, on the other hand, are not limited in duration, but rather protect "the whole of life." (Graves, 1994) Unlike term insurance contracts, which represent pure insurance, the typical whole life contract is a combination of insurance and tax-deferred savings. The typical "ordinary life" product has fixed (nominal) level premiums and a fixed (nominal) death benefit or face value. As demonstrated in Figure 1, the cash values of these policies rise over time, while the pure insurance component declines. The standard practice among life insurers is for the cash value to equal the face value by age 95 or age 100 (Graves 1994). According to the 1995 Survey of Consumer Finances, the median whole life insurance policy held by individuals age 70+ had a cash value that was $67 \%$ of the face value. This means that only $1 / 3$ of the reported face value of whole life policies represents insurance. Most whole life policies have provisions that enable individuals to borrow against the cash value of the policies, and as such provide some degree of liquidity. Importantly for the annuity offset model, the cash value of a policy is not a negative annuity, but rather represents a non-annuitized financial asset, much like a savings account. While it is true that the cash value of a life insurance policy may be left to one's heirs as a bequest, a large cash value policy would not be indicative of over-annuitization any more than would the holding of a large savings account.

As important as this distinction may be between term and whole life insurance, previous empirical work on the elderly was unable to distinguish between them. The Retirement History Survey provided data only on the total face value of all life insurance policies. Thus, to the extent that ownership of whole life more closely resembles tax-deferred savings than insurance, previous 
researchers were unable to disentangle these two potentially different effects. For example, suppose high income individuals are more likely to purchase whole life insurance as a form of tax-deferred savings. Because these individuals are high income, they also receive a higher Social Security benefit at retirement. This could lead to a spurious correlation between total life insurance holdings and the level of the Social Security benefits. As we shall see, this co-mingling of insurance and tax deferred savings has an important impact on the results.

\subsection{Group Versus Individual Coverage}

Another relevant distinction between types of life insurance that may be important to this model is between "group" and "individual" coverage. Group life insurance policies are commonly provided through employers or unions. An example of a typical group life policy is one that insures an employee for a fixed multiple of their salary. Individual contracts, on the other hand, are purchased directly from the insurance company, most often through an insurance agent or broker.

The primary distinction between these policies is that individual life coverage is clearly a "choice" variable, whereas group coverage is often automatic with employment. While in many instances group coverage simply substitutes for individual coverage that would have been purchased anyway, it will also cover some individuals who may have chosen to hold no life insurance if not covered through their employer. Another reason this distinction is relevant is that since group coverage is usually tied to employment, its purpose is often to protect an employee's family from the loss of future earnings. This purpose for holding life insurance is distinctly different from using life insurance to offset a retirement annuity.

Group coverage is less common among retired elderly households, since most group coverage is tied to employment. Neither the RHS, nor the AHEAD data used in this study, allow for this distinction between group and individual coverage. However, by making use of information about 
the current employment status of an individual, it is possible to extract some information about the effects of this difference.

\subsection{Previous Empirical Results}

Previous empirical support of the annuity offset model rests on two key results. The first is that there exists a strong positive correlation in a cross section of households between the level of Social Security benefits, and the holdings of life insurance. Bernheim estimates that approximately $25 \%$ of households own term life insurance, and based on his findings, are therefore over-annuitized. His central results indicate that they are using term insurance to offset Social Security by roughly 20 cents on the dollar.

Second, Bernheim finds mixed evidence to suggest that a portion of the total life insurance holdings are negatively correlated with total lifetime resources, and thus represents an inferior good. Importantly, in his most direct specifications, he finds that life insurance coverage is actually increasing with resources for married couples with children. Only when he imposes more structure on the problem to overcome problems of data contamination does he find a consistently negative and significant resource effect. However, this approach is unable to directly identify the effect of resources on term life insurance, and instead relies on modeling total holdings as the sum of two separate processes (one representing term and one representing whole, but each unidentified in advance) and testing the sign of various coefficient combinations.

The difficulty with these results is that the potential for bias is quite high due to the inability to directly identify the term insurance component of total life insurance holdings. Suppose that individuals purchase insurance during their working lives in order to protect their spouse and children from the loss of their human capital in the event of an early death. Individuals can choose between term and whole life insurance to meet this insurance need. The annual premium on a 
whole life contract is higher than the premium on a term life contract because some of the additional premium essentially goes into a savings account that benefits from tax-deferred inside buildup. Because of this, the whole life contract is more attractive, all else equal, to an individual in a higher marginal tax bracket. Therefore, high earners (who therefore face higher marginal rates) have the most to gain from purchasing whole life contracts. High earners will also be paying more in Social Security payroll taxes, and will thus have a higher benefit upon retirement. Thus, to the extent that whole life contracts held by the elderly represent "residue" from decisions made early in life to protect human capital, this would induce a spurious positive relationship between SSB and whole life insurance coverage.

Two pieces of evidence suggest that this scenario is a strong possibility. First, according to a life insurance ownership study conducted by LIMRA, the median age of the oldest life insurance policy held by individuals age $70+$ was 42 years, suggesting that most policies were in fact purchased during one's working life. Second, there is a clear positive relationship between ownership of whole life insurance and income during one's working life. For example, if we focus on working age individuals (age 22-65) in the 1995 Survey of Consumer Finances, we find that only $20 \%$ of individuals with incomes under $\$ 30,000$ own a whole life insurance policy. Of those with annual incomes between $\$ 30,000$ and $\$ 60,000,33 \%$ own a whole life policy. Nearly half (48\%) of those earning over $\$ 60,000$ per year own a whole life policy. This relationship is not biased by the age-earnings profile, as a nearly identical trend emerges when one examines ownership patterns conditional on age. Thus, whole life insurance ownership during one's working life is clearly correlated with income, and thus with OASDI contributions. If individuals continue to hold these policies after retirement, this will lead to a positive correlation between the level of Social Security benefits and whole life insurance ownership. Newly available data allows for a separation of total 
life insurance into whole versus term life policies, and as such provides a more direct test of the model.

A second potential source of spurious correlation is that some individuals in the Bernheim study were still in the work force. His 1975 RHS sample was comprised of individuals age 65-69. According to Department of Labor statistics, in that year the labor force participation rate of individuals age $65-69$ was $31.7 \%$. High labor force participation can lead to bias in the annuity offset test for two reasons. First, individuals still in the workforce still have positive human capital to protect, and may hold life insurance for this reason. If these individuals also have higher Social Security benefits due to their strong attachment to the labor force, this could induce a positive correlation between benefits and insurance coverage. Second, employed workers are more likely to be automatically covered by group insurance plans. Therefore, even if the person has no demand for insurance, he or she may be insured. If employed workers are more likely to have higher Social Security benefits, a spurious positive correlation would result.

\section{Data \& Methodology}

This paper uses data on elderly households from the first wave of the Asset and Health Dynamics of the Oldest Old (AHEAD) survey. Fielded in 1993/94, this survey collected detailed financial and demographic data on community based individuals born 1923 or earlier, so they are age 70 and above at the date of the survey. The questionnaire collects detailed information on economic and demographic variables, health, work status, and importantly for this study, life insurance coverage.

There are several advantages to the use of this data over the earlier work completed using the Retirement History Survey. First, it allows for the important distinction between term life and 
whole life insurance coverage. While it still does not permit the decomposition of whole life into its cash versus insurance value, the fact that we can distinguish between pure term policies and whole policies none-the-less represents an important improvement over the total face value of all insurance. Second, because the data consists of individuals age 70+, nearly all of them are retired. This is important both because this means that the individuals no longer carry life insurance to protect against the loss of human capital, and because it is significantly less likely that the individual will be covered by a group life insurance plan through the employer. Therefore, a test of the annuity offset hypothesis will not be contaminated by work-related reasons for insurance coverage. Third, the data is much more recent than the RHS, which is potentially important due to the clear long-term decline in the life insurance coverage of households over the past three decades (LIMRA, 1992). Fourth, because of the advanced age of the cohorts, there are large enough samples to investigate the behavior of widows and couples separately. This may be an important distinction because at least one alternative to the annuity offset hypothesis is relevant to couples but not to widows. This is the notion that elderly couples may use life insurance to re-allocate wealth across states of spousal survival.

The primary disadvantage of the AHEAD data is the fact that it does not currently contain information on the earnings histories of respondents. As a result, it will not be possible to exactly replicate the specification of lifetime resources as used in Bernheim's work on this subject. However, the information on current income from Social Security and pension plans is quite detailed, and along with information on financial assets it is possible to construct a very good measure of resources available to the household from the date of the survey forward.

This analysis will focus on two subsets of households in the AHEAD data set. The first is married couples in which both spouses were interviewed, and for which we therefore have complete 
information about important characteristics of both spouses. The second set consists of male widowers and female widows (hereafter often referred to collectively as widows), i.e., formerly married individuals who lost their spouse to death. Excluded from this analysis are "never married" individuals, both because of small sample sizes and because they are less likely to have children or grandchildren to which they may wish to bequeath. Also excluded are single divorcees, due to small sample sizes and the fact that the survey lacks important information about their former spouse. The resulting sample size for married couples ranges from 1750 to 1950 households, and from 2600 to 2800 widows and widowers. The "range" of households arises from missing data for some versions of the dependent variable. For example, an individual may state that they do not own a whole life policy, but that they do own a term life policy with an unknown face value. My decision rule was to include the maximum number of households possible, so this person would be included in the whole life regressions, but excluded from the term life and total life regressions due to missing data. I have conducted extensive checks to ensure that the results were not sensitive to this selection process, and found that the basic results are unchanged.

In order to test for the effect of Social Security benefits and total resources on the holdings of life insurance, I use the following econometric specification:

$$
\mathrm{LI}_{\mathrm{i}}=\operatorname{Max}\left\{0, \beta_{0}+\beta_{1} \mathrm{SSB}_{\mathrm{i}}+\beta_{2} \mathrm{LR}_{\mathrm{i}}+\beta_{3} \mathrm{X}_{\mathrm{i}}+\varepsilon_{\mathrm{i}}\right\}
$$

LI is the face value of life insurance. In some specifications, this will represent total face value, while in others I will limit it to term life or whole life only, in order to account for the cash value bias discussed earlier. SSB represents the annual flow of benefits from Social Security. LR is a vector of characteristics that attempts to capture components of lifetime resources. It includes the variable PVR, which equals the expected discounted present value of resources, including net 
worth, social security wealth, and pension wealth. Because life-time earnings records are not yet available in the data set that I use, the LR vector also includes a number of variables which proxy for the effect of lifetime earnings. These include nine occupation indicators and four educational attainment indicators. For specifications involving couples, these indicator variables are all included separately for each spouse. $\mathrm{X}$ is a vector of other relevant demographic characteristics, including age, gender, race, and whether the respondents have any living children.

I will show results using two different estimation procedures. For comparability with Bernheim's study, I will first assume the normality of $\varepsilon$ and report results from a Tobit specification. One might be concerned about the possibility of heteroskedasticity in the unobservables in the demand for life isnurance, which would render the Tobit results inconsistent. Therefore, I will also report results using simple OLS regressions with White corrected standard errors. As the results will indicate, to the extent that heteroskedasiticy biases the Tobit results, it appears to do so in a direction that favors the annuity offset model. Further specification checks using a censored LAD estimator, or modeling the heteroskedasticity in a multiplicative form, similarly indicate that any such biases tend to work in favor of the annuity offset model. This phenomenon is captured by the OLS estimates, so I limit reported results to Tobit and OLS.

Equation (1) closely approximates the main specification used by Bernheim in his test of the annuity offset model in the Retirement History Survey, with three primary differences. The first is that Bernheim was restricted to using total face value of all life insurance as his dependent variable, whereas the current study can examine whole and term separately. The second difference is in the construction of the measure of total resources. The definition used here, PVR, is net worth plus the present value of future income from Social Security and pensions, and thus represents resources available from today forward. Bernheim's measure was the present value of lifetime earnings plus 
the present value of Social Security and pensions, and thus represented total lifetime resources. The third difference is that the current study examines behavior of widows and couples in separate regressions. Bernheim ran his model on all households, with appropriate indicators for marital status, but excluded individuals who had been widowed more than 6 years.

\section{Results}

Table 1 presents summary statistics on life insurance ownership among age 70+ households in the AHEAD data. Several features of the data are worth noting. First, men are more likely to hold all types of life insurance than are women. Nearly $62 \%$ of widowed men own a life insurance policy, versus only $49 \%$ of widowed women. Among currently married couples, $72 \%$ of men are covered by at least one policy, versus only $55 \%$ of married women. Looking at term and whole life ownership separately, the same basic pattern emerges, in that men are always more likely to hold insurance than women. In addition, men always hold more insurance conditional on owning, than do women.

A second feature of the data is that most policies tend to be quite small, though the distribution is fairly skewed. The median married household owns a total of $\$ 10,756$ of life insurance, a figure that includes all types of life insurance on both spouses. Among widowed households, it is even smaller, with a median value of $\$ 5000$ for men, and $\$ 2500$ for women. However, the means are roughly two to three times larger than the medians, which is driven by the fact that a small fraction of households own very large policies. For example, the $95^{\text {th }}$ percentile of total household coverage among married couples (conditional on owning) is $\$ 113,000$. The $95^{\text {th }}$ percentile of coverage for male widowers is $\$ 50,000$. 
The third broad pattern to recognize is that marital status is an important margin along which insurance coverage differs. Married individuals are much more likely to own life insurance than are widows or widowers of the same gender, and hold more of it conditional on owning. There are many reasons why this could be true, including reasons that might bear upon the relative importance of using life insurance to protect a spouse versus providing a bequest. However, a large part of these differences are undoubtedly attributable to differences in the financial status of married and versus widowed households, which is not captured in these simple tabulations.

\subsection{Test of Implication \#1: "No simultaneous holdings"}

The first implication of the annuity offset model, and the one easiest to test in the data, is the notion no individual would choose to simultaneously hold life insurance and annuities. This is because they are offsetting transactions, each of which may cause the individual to incur transactions costs or "loads" to the fact that private insurance markets are not actuarially fair.

This assumption is clearly violated by the data in Table 2 . This is particularly notable if one follows the Bernheim approach of treating annuities from pension plans as voluntarily purchased. Of all married households, $50 \%$ own both a private pension and some form of life insurance. Among widows and widowers, $21 \%$ own both private pension annuities and life insurance. There are reasons to suspect that private pensions are not strictly "voluntary," especially among those age 70+ who were likely covered for most of their careers in traditional defined benefit plans. However, even if we restrict ourselves to privately purchased, non-pension annuities, $6.6 \%$ of married couples own both. Since only $7.7 \%$ of the sample own such an annuity, however, this means that $86 \%$ of those married households who have purchased a private, non-pension annuity also own life insurance. 
These numbers are not surprising, since in Bernheim's own sample $36 \%$ of households, which included both married and widowed individuals, owned both pensions and life insurance. He attributed this finding to data contamination, namely the fact that he was unable to distinguish between term and whole life insurance. If the $36 \%$ of people holding both were really holding whole life policies with cash values approaching their face values (i.e., they contained very little insurance), then this finding would not be inconsistent with the annuity offset model. However, using the AHEAD data, we can see that this is not the explanation. Roughly one third of married households own both straight term life insurance policies and a private pension, as do $13 \%$ of widows. Perhaps the "purest" test of the model is to use term life insurance and non-pension annuities. In this case, $3.8 \%$ of couples hold both. Importantly, one half of all married households that own a non-pension annuity also have life insurance coverage. This is clearly inconsistent with the annuity offset model.

\subsection{Test of Implication 2: Positive Correlation between Insurance and Social Security}

The second, and arguably the most important, implication of the annuity offset hypothesis is that there should exist a positive correlation between term life insurance coverage and the level of Social Security benefits. The heart of this hypothesis, as outlined in Section 1, is that when individuals have higher Social Security benefits, they want to buy fewer private annuities and more life insurance.

Table 3 reports Tobit results for equation (1) in the combined sample of widows and widowers. Column(1) reports Tobit coefficients for the case in which total face value of all life insurance holdings (term plus whole) is the dependent variable. Column (2) reports coefficients for the OLS specification. Columns (3) and (4) repeat this analysis with the dependent variable limited to term 
life insurance, and columns (5) and (6) limit the dependent variable to the face value of whole life insurance.

The coefficient on SSB (annual Social Security Benefit) is the coefficient of interest for testing this implication of the model. If the annuity offset model is correct, the coefficient should be significantly positive. Looking first at column 1, we can see that this relationship does hold for total life insurance coverage in the Tobit specification, with a coefficient of 0.48 that is highly significant. Using the well-known approximation that the marginal effect can obtained by scaling the parameters by the probability in the uncensored region yields a marginal effect of another dollar of Social Security benefits of approximately $\$ 0.22$ of life insurance coverage. Column (2) repeats the analysis using OLS, and finds a nearly identical effect of 0.22 , though the large (Whitecorrected) standard errors render this coefficient insignificant.

We can translate the life insurance face value into an annuity flow by dividing by the appropriate annuity factor, i.e., the actuarial present value of a $\$ 1$ annuity flow. Using a real interest rate of $3 \%$, this factor is approximately 10 for the average individual in the AHEAD sample. Therefore, we find that life insurance is offsetting the flow of Social Security benefits on the margin by approximately 2.2 cents on the dollar. This offset is much lower than the $10-20$ cent offset that Bernheim found because the current sample is of widows and widowers only, while Bernheim's results were for a mixed sample. Results for couples, discussed below, show a somewhat larger offset that falls in the lower end of the Bernheim offset range.

Columns (3) through (6) of table 3 makes the important distinction between term and whole life insurance. Columns (3) and (4) report the results for the case in which only Term life insurance is treated as the dependent variable. Relative to the results for columns (1) and (2), the difference is striking. The Tobit coefficient falls to 0.04 , and is statistically no different from zero. The Tobit 
coefficient for SSB in the whole life insurance specification in column (5), on the other hand, is large and significant -- the Tobit coefficient on SSB is 1.22 and is highly significant. The OLS results are again similar to the marginal effects that arise out of the Tobit coefficients, but are not significant. It therefore appears, at least in the sample of widows and widowers, that the central implication that Social Security benefits will be positively correlated with term life insurance coverage does not hold. While there is a significant positive relationship found between total life insurance coverage and Social Security in the Tobit specifications, this relationship appears to be driven more by whole life insurance than term coverage, and even this relationship is not always significant in the OLS case.

As discussed by Bernheim and earlier in this paper, the annuity offset model is really a model about term life insurance. Yet the primary implication of this model, that term life insurance ownership will be an increasing function of the level of Social Security benefits, is clearly rejected by the data. The relationship between whole life insur ${ }^{1}$ ance and Social Security, on the other hand, is much stronger but subject to numerous sources of bias. As discussed, by age 70, whole life insurance primarily consists of tax-advantaged savings, and therefore does not serve to "undo" annuitization any more than holding other financial assets. Since the individuals who have the most to gain from the inside build-up associated with whole life policies are people who were in higher tax brackets while younger (and who therefore are also likely to have higher Social Security earnings), the observed relationship may be driven more by tax consequences than by a desire to offset a government annuity.

Table 4 repeat the analysis for the male widowers only, and finds a similar pattern. In the specification using total life insurance as the dependent variable, there is a significant positive effect 
of SSB in the Tobit specification, and it is much larger in magnitude. Once again, however, when we decompose total life insurance holdings into the two types, we find that the positive relationship is being driven entirely by whole life policies. The OLS results again show similar, though insignificant, marginal effects. Table 5 repeats the same analysis for female widows. In this case, the coefficient on SSB in the total life insurance regression falls short of significance, and is smaller in magnitude than for males. More importantly, the coefficient on SSB in the term life insurance specifications continues to be small and insignificant. The only specification in which the SSB coefficient is significant is for the Tobit specification in the whole life insurance regression.

Table 6 presents results for married couples. Focusing on column (1), we again see that the coefficient on SSB in the "total life insurance" specification is a positive and significant 0.91 . This offset is similar to what Bernheim found, though at the lower end of his range. Once again, however, the split of total insurance into its two types yields dramatically different results. The coefficient for Term insurance in column (2) is only 0.27 , and is not significant at the $95 \%$ level. The coefficient on SSB in the Whole insurance specification (column (3)), on the other hand, is a significant 1.46. Repeating the analysis with OLS regressions, we again find no significant correlation between SSB and life insurance ownership. As in the case with widows and widowers, the significant Tobit results appear to be driven primarily by a whole life insurance, not the term insurance that the model is meant to represent.

Table 7 repeats the analysis on the sub-sample of married couples in which neither spouse is currently in the workforce. This distinction is quite important, as even the Tobit coefficient on total life insurance is no longer significant. There are two important reasons to think that working couples may differ from non-working. First, an employed individual still has some (albeit small) human capital to protect, just as a younger working age individual does. Second, a worker is more 
likely to be covered by a group insurance plan through the employer. In either case, if workers also have higher Social Security benefits because of a stronger attachment to the labor force, this will induce a positive correlation between SSB and life insurance, even in the absence of a desire to undo annuitization.

Table 8 reports results similar to table 6 , except that the dependent variable is life insurance coverage on the husband only. The pattern of coefficients on SSB is similar to those found in table 6. Again, any positive correlation is limited to the total or whole life specifications, and is significant only in the Tobit specifications. Table 9 shows the results for the sample of married women, and again we see the familiar pattern of coefficients.

In short, there is no evidence to suggest that term life insurance ownership among retired elderly households exhibits the correlation with Social Security benefit levels that the annuity offset model demands.

\subsection{Test of Implication \#3: Term Insurance as an Inferior Good}

The third implication of the annuity offset model is that term life insurance will behave as an inferior good with respect to life-time resources. This is simply because retirement consumption is viewed as a normal good, and therefore the demand for annuities should be an increasing function of resources. Since term insurance is to behave as a negative annuity, this means that the demand for term insurance should be declining with total lifetime resources.

I am unable to exactly replicate Bernheim's measure of lifetime resources because access to Social Security earnings records is unavailable. However, we do observe other components of resources, including the actuarial present value of pensions, Social Security, housing wealth, and financial net worth. I construct the variable PVR (Present Value of Resources) to be the sum of 
these resource variables. In addition, I am able to use indicator variables for education and occupation to proxy for lifetime earning effects.

Using a measure of lifetime resources that included lifetime earnings and the present value of pensions and Social Security, Bernheim found mixed results in his test of this implication. Specifically, in his basic Tobit results, he found that the lifetime resource effect was negative for the average childless couple, but positive and insignificant for couples with children. He finds better support for the notion that at least some portion of total life insurance demand behaves as an inferior good by conducting "refined estimates" which model total life insurance holdings as the sum of two distinct, but separately unidentified, processes. Based on these refined estimates, he concludes that the term part of total life insurance ownership is the component that is behaving like an inferior good.

Looking at the coefficient on PVR among widows and widowers (tables 3, 4 and 5) and among married couples (tables 6 through 9), we find no significant relationship between PVR and term life insurance. While the sign of the coefficient is negative in some of the term life insurance specifications, it is not even approaching significance at any standard level of confidence. The coefficient on PVR in the whole life insurance specifications, and as a result in some of the total life insurance specifications, is strongly positive. This latter finding is consistent with Bernheim's conclusion that term and whole life insurance respond rather differently to variation in total resources. In the AHEAD data, however, there is no evidence that term insurance is behaving like an inferior good.

\subsection{Test of Implication \#4: Term Insurance Owners Consume Less than Social Security Income}

The fourth and final empirical implication of the annuity offset model derives from the definition of being "over-annuitized" by Social Security. The basic notion behind this model is that 
household bequest motives are sufficiently strong that their desired consumption level is less than the annuity provided by Social Security, and that they would therefore prefer to keep some of their wealth un-annuitized in order to leave it to their heirs.

Conceptually, this is a straightforward implication to test, since it requires the simple comparison of consumption to the income provided by Social Security. If a household is consuming more than the Social Security benefit, then they are not over-annuitized. However, this implication is difficult to test directly in the AHEAD data due to the fact that a good measure of consumption is difficult to construct with currently available data. Therefore, I will rely on less direct methods to infer the extent to which households wish to consume less than their Social Security income.

It is useful to first consider a household's dynamic budget constraint:

$$
\mathrm{W}_{\mathrm{t}+1}=\left(\mathrm{W}_{\mathrm{t}}-\mathrm{C}_{\mathrm{t}}+\mathrm{SSB}_{\mathrm{t}}+\mathrm{Y}_{\mathrm{t}}\right)(1+\mathrm{r})
$$

where $\mathrm{W}_{\mathrm{t}}$ represents financial wealth at period $\mathrm{t}, \mathrm{C}_{\mathrm{t}}$ is consumption in period $\mathrm{t}, \mathrm{SSB}_{\mathrm{t}}$ is the income flow from Social Security, and $\mathrm{Y}_{\mathrm{t}}$ is the income flow from other (non-Social Security) sources. If it is true that individuals are over-annuitized by Social Security, it must be the case that $\mathrm{SSB}_{\mathrm{t}} \geq \mathrm{C}_{\mathrm{t}}$. If not, then the constraint of the mandated Social Security annuity is non-binding, and needs not be offset by life insurance. Since we do not directly observe consumption in the AHEAD survey, this test must necessarily be indirect. To be over-annuitized by Social Security requires $\mathrm{SSB}_{\mathrm{t}}-\mathrm{C}_{\mathrm{t}} \geq 0$. This implies:

$$
\mathrm{W}_{\mathrm{t}+1}-\mathrm{W}_{\mathrm{t}}(1+\mathrm{r}) \geq \mathrm{Y}_{\mathrm{t}}
$$

In other words, we need the amount of net saving done by a household to exceed the level of non-Social Security income that they receive during the period. That is, they must be saving some fraction of their Social Security payment in addition to all non-Social Security income. According 
to the annuity offset model, households that own term life insurance should be saving all non-Social Security income, and then supplementing this bequeathable savings with life insurance.

One simple way to test for this is to make use of a question asked in the first wave of the AHEAD survey:

"Not counting any money or assets that you may have given children or others, did you [and your (husband/ wife/ partner] use up any of your investments or savings during (1992/1993) to pay for expenses?

If households are spending down their existing non-annuitized assets in order to pay for current consumption expenses, then they must be consuming at least as much as their current total income, and therefore at least as much as their Social Security income. Therefore, these individuals would have no reason to hold life insurance.

Table 10 shows that approximately one quarter of all households spend down assets in 1992/93. Importantly, the overwhelming majority of these households own life insurance, and in particular, term life insurance. In fact, the proportion of those owning term life insurance who spend down assets does not appear to be very different from the proportion of those not owning term insurance who spend down assets, for both widows and couples. Specifically, $24 \%$ of widows and $25 \%$ of couples who own term life insurance engaged in a spend-down of financial assets. This test clearly understates the proportion of term life insurance owners who are consuming more than their Social Security benefit level, as it does not account for consumption out of non-Social Security income. If a person also has pension or investment income, for example, the individual may consume in excess of Social Security, and yet still be a net saver.

\subsection{Summary of Annuity Offset Tests}

All four of the major implications of the annuity offset model fail empirical testing in the AHEAD data. As a result, it seems clear that this model does not explain life insurance behavior of 
elderly households. This leads to the obvious next question of "what is the alternative hypothesis?" This is the subject of the next section.

\section{Alternative Explanations}

There are a number of plausible alternative hypotheses that could explain why elderly individuals and couples hold life insurance. These alternatives share the common feature that none of them rely on the four empirical implications of the annuity offset model. That is, these hypotheses are still quite plausible even knowing the results of Section 4. It is not the goal of this paper to conduct a definitive test to select from among these alternative hypotheses. I will, however, present some suggestive evidence to provide direction for further research. The four alternative hypotheses I discuss below include:

(i) "Couple Protection": Elderly couples use life insurance to insure against loss of pension or Social Security benefits upon the death of the first spouse.

(ii) "Inertia": Life insurance holdings are simply "residue" from attempts earlier in life to insure human capital.

(iii) "Estate Tax Planning": Life insurance is used to assist with estate tax planning in wealthier households, such as to provide liquidity.

(iv) "Funeral Expenses": Many elderly view life insurance as their burial money.

\subsection{Couple Protection:}

The first of these alternatives, the couple protection model, assumes that married couples are purchasing life insurance in order to re-allocate life-contingent income. For example, suppose a husband has a pension plan which is being paid out as a "joint and 50\% contingent" annuity. This type of annuity treats the spouses asymmetrically. If the wife dies first, the husband continues to receive the full benefit. If the husband dies first, on the other hand, the pension income paid to the 
wife drops by $50 \%$. If the couple decides that they would like to re-allocate income from the "husband only" state to the "wife only" state, one way to do this is to purchase a term life insurance policy on the husband.

The evidence on this alternative is mixed. First, it cannot explain the fact that $62 \%$ of widowers and $49 \%$ of widows hold life insurance policies. Second, Auerbach and Kotlikoff $(1987,1989)$ tested this model of couples using several data sets, including the RHS, and found little support for the model's implications. Specifically, they calculated the decline in resources that a married individual would face upon the death of their spouse, and used this variable as a predictor of life insurance ownership on the spouse. They found that most households do not adequately insure spouses against the potential resource loss associated with widowhood.

On the other hand, $95 \%$ of husbands in the AHEAD sample who own term life insurance name their spouse as the policy beneficiary. If the insurance was truly being held to leave as a bequest to children, there is no obvious reason to leave the policy to the surviving spouse instead. Further exploration of this alternative hypothesis using the AHEAD data is being conducted in a separate paper.

\subsection{Inertia}

The second alternative hypothesis is that the elderly hold life insurance while old only because they held it when they were young. This could reflect rational or irrational behavior on their part, such as the case when an individual rationally keeps a policy because it represents a good value from here on. This could be because the policy is already paid up, or because someone else is paying for the policy (e.g., a child or a former employer). For example, roughly $40 \%$ of the individuals in the AHEAD data who are covered by a term life insurance policy are currently paying no premiums. Alternatively, may have had a multi-year term policy with flat or level 
premiums, and therefore the policy is better than actuarially fair deal from this time forward because the individual has essentially pre-paid.

There are also non-rational reasons that one might hold onto a policy that was bought earlier in life. Samuelson \& Zeckhauser (1988) provide evidence of status quo bias in decision making. They point out that most decisions, such as an elderly individual's decision about how much life insurance to hold, has a status quo alternative of "doing nothing" or "maintaining one's current or previous decision." Using evidence from a series of experiments, as well as data on retirement plan choice, they show that individuals have a strong propensity to stick with the status quo. They attribute this to the presence of "transition costs or uncertainty, cognitive misperceptions, or a psychological commitment stemming from misperceived sunk costs, regret avoidance, or a drive for consistency."

There are several pieces of evidence that suggest inertia may hold affect a significant fraction of the sample. First, data from the 1992 Life Insurance Ownership Study from the Life Insurance Market Research Association indicates that most policies held by the elderly are quite old. When asked the age of the newest life insurance policy held, the median response among those age 70+ was 32 years. The median age of the oldest policy was 42 years. Fully $30 \%$ of these elderly individuals bought their newest insurance policy before the age of 30, and have not purchased any additional insurance since that time. Half of those owning insurance have not bought a policy since the age of 43. It thus appears that the majority of policy owners have not purchased any insurance for many decades, at least raising the possibility that their continued ownership is due to a failure to cancel.

On the other hand, $17 \%$ of those who own life insurance bought their most recent policy since the age of 65. According to a LIMRA Buyer's Study (1996), only 8\% of all life insurance policies 
sold by agents to individuals age 65+ were term policies. Most of the rest were whole life policies, which are commonly used for estate planning purposes. The average size of the policies sold to those ages $65+$ was $\$ 92,800$, with an annual premium of $\$ 4,698$. These are quite large policies compared to the average policy size found in the AHEAD data, indicating that these individuals are likely to be wealthier than average and more concerned with estate planning. While these households may well be concerned about bequests, it is highly unlikely that they would be purchasing large cash value policies in order to offset Social Security.

\subsection{Estate Tax Planning}

The third alternative hypothesis is that individuals hold life insurance to aid in estate planning. There are several reasons why a wealthy household that would be subject to estate taxation upon death would use life insurance as part of an estate planning strategy. First, owners of family business may wish to provide heirs with sufficient liquidity to pay for the estate taxes associated with the value of the business operation, in order to avoid the need to liquidate business assets. Holtz-Eakin, Phillips, and Rosen (1999) explore this point in detail. They find that, other things being the same, business owners purchase more life insurance than other individuals.

While it is undoubtedly true that some high wealth households use life insurance as an effective estate planning tool, this simply cannot explain more than a small fraction of households in the AHEAD data. Fewer than 5\% of households in the data have a combined net worth and life insurance face value in excess of $\$ 600,000$, which was the point at which the estate tax becomes an issue for households at the survey date.

\subsection{Funeral Expenses}

The fourth alternative hypothesis is that elderly individuals view life insurance policies as their "burial money." This could be due to a mental accounting approach to portfolio choice (Thaler, 
1985), or as a rational way to circumvent the probate process. Either way, this "burial money" notion may explain the preponderance of small face value policies in the sample, since according to the National Funeral Directors Association, the average cost of a funeral in 1997 was \$4,782. Hurd and Smith (this volume) show that total out-of-pocket death expenses, which includes out-of-pocket medical and funeral expenses, for decedents in the Ahead data average $\$ 8,934$. For comparison, the median amount of total life insurance coverage is $\$ 5000$ among male widowers, $\$ 2500$ among female widows, $\$ 3000$ among married women, and $\$ 9000$ among married men. It seems reasonable to suspect that many of these small policies are held for the purpose of paying for final death-related expenses. This notion is present in popular financial planning books as well. The author of one such book tells the story of a conversation with a widow who asked him to review her finances. She was financially well off, with over $\$ 600,000$ in net worth, and annual living expenses of only $\$ 30,000$. When he asked her why she was carrying a term life insurance policy that was costing her several hundred dollars a month in premiums, she replied "that is to bury me" (Gardiner, 1997).

A study conducted by the Life Insurance Market Research Association confirms that life insurance is frequently purchased with the intention of using the proceeds to pay for one's burial. $83 \%$ of widows report using life insurance proceeds of their deceased spouse primarily to pay for death-related expenses. LIMRA also reports that paying for death-related expenses is the most commonly cited reason that consumers give for purchasing life insurance.

One reason that life insurance is a popular device for paying for death expenses is that it avoids probate if paid to a named beneficiary (Graves, 1994). Probate proceedings can "tie-up" ordinary assets for many months, so that family members are unable to use these assets to pay for funeral or other death related expenses. The proceeds from a small life insurance policy, because it 
avoids the probate proceedings, can provide the decedent's family with timely access to funds with which to pay for these expenses.

\subsection{Putting It All Together}

Once we account for all the behavior that is directly inconsistent with the annuity offset model and/or potentially explained by alternative hypotheses, what fraction of households exhibit behavior that can be explained only by the desire to offset annuities? A simple running tabulation presented in Table 11 shows that it is likely to be a trivial fraction of the population - far less than the $25 \%$ figure resulting from earlier analyses.

Table 11 starts with the full population of widows and widowers in the left column, and married men in the right. As the chart shows, approximately half of all widows and $71 \%$ of married men own a life insurance policy. However, the annuity offset model is really a model of term life insurance, which means we are really concerned about the $31.5 \%$ of widows and the $41.6 \%$ of married men who own a term policy. Next we can subtract off those households which purchase a life-annuity, since these households would clearly not purchase life insurance to offset Social Security, only to turn around and annuitize additional resources. If we follow Bernheim's lead in treating life-contingent pension annuities as a choice variable, we can further reduce the sample to only $17.7 \%$ of widows and $14.5 \%$ of married men.

Next, we can eliminate those households who are spending down their financial assets for consumption, since these individuals are also clearly not constrained by the Social Security income floor. At this point, we have $13.9 \%$ of widows and $10.7 \%$ of married men still in the pool. Now let us account for individuals whose term life insurance coverage costs them nothing. The reasoning here is that if an individual can receive a policy at zero marginal cost, then it is perfectly rational for them to keep it regardless of whether they have bequest motives or not. In any case, since they do 
not have to use the Social Security benefits to pay for the premium, they are not offsetting the annuity in any direct way. This leaves us with $9.2 \%$ of widows and $8.6 \%$ of married men. Using similar logic, we can eliminate those for whom the term premium is an actuarially advantageous deal. Specifically, I exclude those whose term premium is less than half of the actuarially fair term premium of a 70 -year old in 1993.

For married couples, I eliminate those who name their spouse as the beneficiary, since this means the policy may be held more for spousal protection than for bequest purposes. Finally, let us take the funeral expense notion seriously, and assume that any policy with a face value of under $\$ 5000$ is essentially the individual's "burial money." This reduces the sample to $2 \%$ of widows and $0.5 \%$ of married men.

The calculations in Table 11 are meant to be illustrative only, and one can certainly quibble with any one of the above exclusion restrictions. These figures demonstrate, however, that one can "explain away" the finding that individuals use life insurance to offset Social Security. In short, with a few simple assumptions one can show that only a small fraction of households may overannuitized by Social Security because they have strong bequest motives.

\section{Summary \& Future Directions}

This paper has presented substantial evidence that the reason the elderly hold life insurance is not to offset mandated annuitization in the form of Social Security in order to leave a bequest. Four empirical implications of the annuity offset model were developed and tested, and all four were found to be inconsistent with the behavior of elderly households in the AHEAD data set.

This finding is relevant to the current debate over the future of the Social Security system because it bears upon the question of whether or not mandatory annuitization is desirable. Were it 
the case that a substantial fraction of elderly households were over-annuitized by the existing Social Security system due to the existence of strong bequest motives, this would be evidence in favor of allowing choice over the annuitization decision. The results of this paper suggest that households are not over-annuitized by Social Security for bequest reasons. Therefore, the simple fact that many elderly households own term life insurance is not a sufficient reason to argue against mandatory annuitization of retirement resources. This finding is consistent with the idea that annuities are of substantial value in the retirement portfolios of elderly individuals (Mitchell, et al 1999, Brown 1999, Friedman \& Warshawsky 1988). As a result, mandatory annuitization may be desirable to overcome adverse selection in the annuity market. However, this conclusion should be tempered by the acknowledgement that individuals can be over-annuitized for reasons other than bequest motives, as suggested in work by Hurd (1987 \& 1989).

This paper then suggests several alternative hypotheses for explaining the large fraction of elderly households that own life insurance. While these alternatives were not subjected to formal empirical testing in this paper, informal evidence suggests that some of these alternatives may be relevant. For example, the fact that the vast majority of policies have been held for several decades suggests that many holdings may be due to inertia from insurance decisions earlier in life. This would be consistent with the "status quo bias" in decision making that has been documented by Samuelson and Zeckhauser (1988) among others. It may also be the case that many small policies are held as a method of pre-paying death expenses, such as funerals.

It has also been found that the majority of policies held by married individuals name their spouse as the beneficiary of the life insurance policy rather than their children. This is at least suggestive that the purpose of these policies may be to provide an adequate consumption stream for a widowed spouse. While this hypothesis found little support in earlier empirical work by 
Auerbach \& Kotlikoff, they suggested that this might in part be due to the poor quality of their data. This hypothesis is being re-examined using the AHEAD data as part of a separate research project. 


\section{REFERENCES}

American Council of Life Insurance, 1996, Life Insurance Factbook, Washington, DC.

Auerbach, A.J. and L.J. Kotlikoff, 1987, “Life Insurance of the Elderly: Its Adequacy and Determinants." In Work, Health, and Income Among the Elderly, edited by Gary Burtless. Washington: Brookings Institution.

Auerbach, A.J. and L.J. Kotlikoff, 1989, "How Rational is the Purchase of Life Insurance,” NBER Working Paper \# 3063.

Bernheim, B.D., 1991, "How Strong Are Bequest Motives? Evidence Based on Estimates of the Demand for Life Insurance and Annuities,” Journal of Political Economy 99, 899-927.

Biggs, J.H., 1987, “Do Social Security Survivor Benefits Crowd Out Private Life Insurance?,” Center for the Study of American Business Working Paper \# 115, Washington University, St. Louis.

Brown, J.R. 1999, "Private Pensions, Mortality Risk and the Decision to Annuitize" MIT Mimeo

Broverman, S., 1986, “The Rate of Return on Life Insurance and Annuities," The Journal of Risk and Insurance 53, $419-434$.

Diamond, P.A., 1997, "Macroeconomic Aspects of Social Security Reform," Brookings Papers on Economic Activity, 1-66.

Friedman, B.M and M.J. Warshawsky, 1988, “Annuity Prices and Saving Behavior in the United States," In Pensions and the U.S. Economy, edited by Z. Bodie, J. Shoven, and D. Wise, Chicago: Univ. Chicago Press (for NBER).

Gandolfi, A.S., and L. Miners, 1996, “Gender-Based Differences in Life Insurance Ownership,” The Journal of Risk and Insurance 63, 683 - 693.

Gardiner, R.M., 1997, Dean Witter Guide to Personal Investing, New York: Penguin Books. 
Goldsmith, A., 1983, "Household Life Cycle Protection: Human Capital Versus Life Insurance," The Journal of Risk and Insurance 50(2), 33 - 43.

Graves, E., editor, 1994, McGill's Life Insurance, Bryn Mawr, Pennsylvania: The American College.

Holtz-Eakin, D., J. Phillips, and H. Rosen, "Estate Taxes, Life Insurance, and Small Business," mimeo, 1999.

Hurd, M.D., 1987, "Savings of the Elderly and Desired Bequests," American Economic Review 77, $298-312$.

Hurd, M.D., 1989, “Mortality Risk and Bequests,” Econometrica 57(4), 779-813.

Hurd, M.D., and J.P. Smith, “Anticipated and Actual Bequests,” This volume.

Hurd, M.D. \& D.A. Wise, 1988, “The Wealth \& Poverty of Widows: Assets Before and After the Husband's Death." The Economics of Aging, NBER, University of Chicago Press, 177200.

Kotlikoff, L. \& A. Spivak, 1981, “The Family as an Incomplete Annuities Market,” Journal of Political Economy 89, 372-391.

Laitner, J. \& T. Juster, 1996, "New Evidence on Altruism: A Study of TIAA-CREF Retirees," American Economic Review 86(4), 893-908.

Lewis, F.D., 1989, "Dependents and the Demand for Life Insurance," The American Economic Review 79,452 - 467 .

LIMRA International, 1996, “The 1995 Buyer Study: A Market Study of New Insureds and the Ordinary Life Insurance Purchased.”

LIMRA International, 1993, "Profiles in Coverage: The Widening Gap in U.S. Life Insurance Ownership." 
Modigliani, F., “The Role of Intergenerational Transfers and Life Cycle Savings in the Accumulation of Wealth," Journal of Economic Perspectives 2(2).

Mitchell, O., J.M. Poterba, M.J. Warshawsky, and J.R. Brown, 1999, "New Evidence on the Money’s Worth of Individual Annuities," American Economic Review, forthcoming.

National Funeral Directors Association, 1998, "Funeral Price Information from the NFDA 1997 General Price List Survey," http://www.nfda.org.

Samuelson, W. and R. Zeckhauser, 1988, “Status Quo Bias in Decision Making,” Journal of Risk and Uncertainty 1, 7-59.

Showers, V.E., and J.A. Shotick, 1994, “The Effects of Household Characteristics on the Demand for Insurance: A Tobit Analysis," The Journal of Risk and Insurance 61, 492 - 502.

Thaler, R.H., 1985, “Mental Accounting and Consumer Choice,” Marketing Science 4, 199 - 214. Warshawsky, M.J., 1988, "Private Annuity Markets in the United States,” Journal of Risk and Insurance, 55(3), 518-528.

Yaari, M., 1965, Uncertain Lifetime, Life Insurance, and the Theory of the Consumer, Review of Economic Studies 32, 137-150. 
</ref_section> 
Figure 1

Proportion of Savings and Insurance Elements in an Ordinary Whole Life Insurance Contract

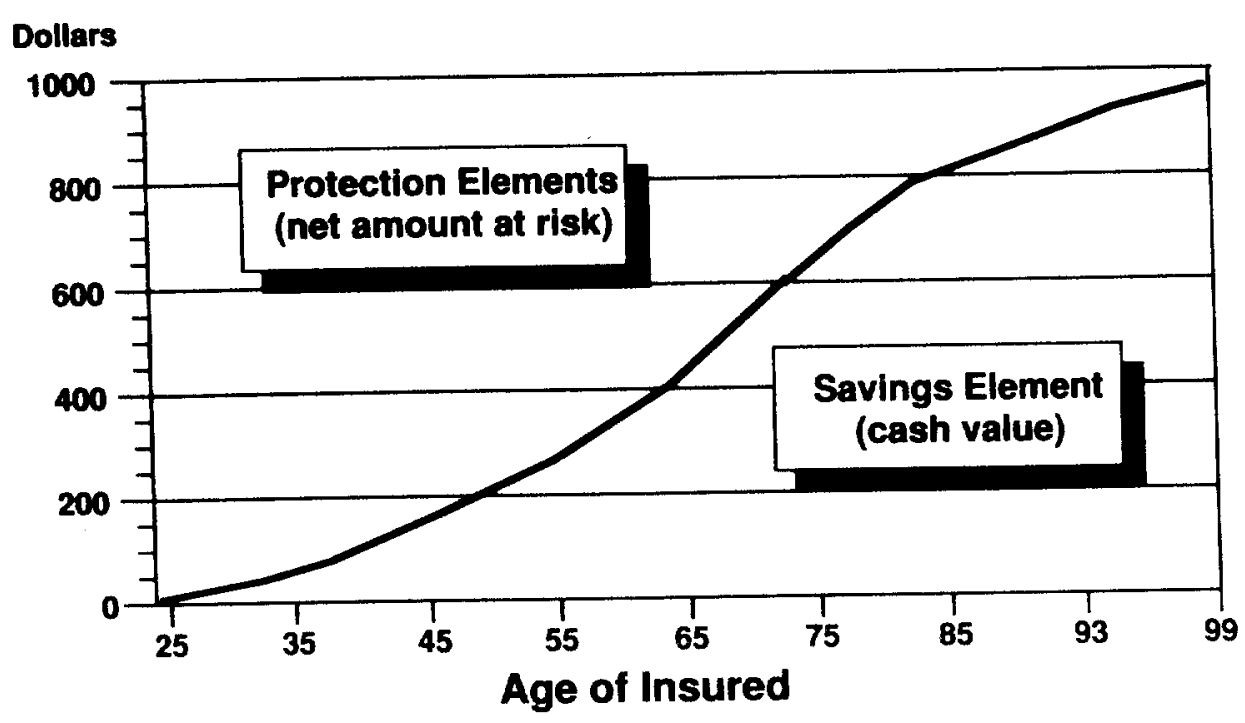

Source: E.E. Grave, ed., McGill's Life Insurance, 1994, The American College. Calculated based on issue age of 25 using 1980 CSO Female life table and a $4.5 \%$ rate of interest. 


\section{Table 1}

\section{Life Insurance Coverage in the AHEAD Data}

\begin{tabular}{|c|c|c|c|c|c|}
\hline & \multicolumn{2}{|c|}{ Widows / Widowers } & \multicolumn{3}{|c|}{ Married Couples } \\
\hline & Men & Women & Men & Women & Household \\
\hline $\operatorname{Pr}($ Owns Any LI) & 0.6184 & 0.4868 & 0.7176 & 0.5540 & 0.7791 \\
\hline \multicolumn{6}{|l|}{ Amount | Own Any } \\
\hline Median & $\$ 5,000$ & $\$ 2,500$ & $\$ 9,000$ & $\$ 3,000$ & $\$ 10,756$ \\
\hline Mean & $\$ 14,280$ & $\$ 5,250$ & $\$ 25,481$ & $\$ 10,718$ & $\$ 31,541$ \\
\hline $\operatorname{Pr}($ Owns Term LI) & 0.3730 & 0.3310 & 0.4174 & 0.3014 & 0.4958 \\
\hline \multicolumn{6}{|l|}{ Amount | Own Term } \\
\hline Median & $\$ 5,000$ & $\$ 2,000$ & $\$ 5,000$ & $\$ 3,000$ & $\$ 7,000$ \\
\hline Mean & $\$ 9,028$ & $\$ 3,841$ & $\$ 12,238$ & $\$ 7,564$ & $\$ 15,313$ \\
\hline $\operatorname{Pr}($ Owns Whole LI) & 0.2749 & 0.1505 & 0.4940 & 0.2577 & 0.5659 \\
\hline \multicolumn{6}{|l|}{ Amount | Own Whole } \\
\hline Median & $\$ 6,000$ & $\$ 3,000$ & $\$ 10,000$ & $\$ 4,500$ & $\$ 14,000$ \\
\hline Mean & $\$ 18,297$ & $\$ 7,189$ & $\$ 33,503$ & $\$ 13,221$ & $\$ 36,119$ \\
\hline
\end{tabular}

Source: Author's tabulations from AHEAD survey, using household weights

Notes: $\operatorname{Pr}($ Owning LI) is the fraction reporting ownership of that life insurance contract type. Amount | Own LI is the mean or median policy size conditional on ownership. 
Table 2

Cross Ownership Patterns for Life Insurance and Annuities

Proportion of Population Holding Both Products

Married Couples: Total Household Coverage

\begin{tabular}{|c|c|c|c|c|}
\hline & \multicolumn{2}{|c|}{ Owns Private Pension } & \multicolumn{2}{|c|}{$\begin{array}{c}\text { Owns Private Annuity } \\
\text { (Excludes pensions) }\end{array}$} \\
\hline & Yes & No & Yes & No \\
\hline \multicolumn{5}{|l|}{ Owns Any LI } \\
\hline Yes & .501 & .278 & .066 & .713 \\
\hline No & .093 & .128 & .011 & .210 \\
\hline \multicolumn{5}{|l|}{ Owns Term LI } \\
\hline Yes & .332 & .164 & .038 & .458 \\
\hline No & .260 & .244 & .038 & .466 \\
\hline
\end{tabular}

Source: Author's tabulations from AHEAD survey, using household weights

Proportion of Population Holding Both Products

Widows and Widowers

\begin{tabular}{|c|c|c|c|c|}
\hline & \multicolumn{2}{|c|}{ Owns Private Pension } & \multicolumn{2}{|c|}{$\begin{array}{l}\text { Owns Private Annuity } \\
\text { (Excludes pensions) }\end{array}$} \\
\hline & Yes & No & Yes & No \\
\hline \multicolumn{5}{|l|}{ Owns Any LI } \\
\hline Yes & .211 & .298 & .030 & .479 \\
\hline No & .137 & .354 & .026 & .465 \\
\hline \multicolumn{5}{|l|}{ Owns Term LI } \\
\hline Yes & .133 & .192 & .039 & .309 \\
\hline No & .216 & .460 & .017 & .636 \\
\hline
\end{tabular}

Source: Author's tabulations from AHEAD survey, using household weights 
Table 3

Tobit \& OLS Results for Widows \& Widowers

\begin{tabular}{|c|c|c|c|c|c|c|}
\hline $\begin{array}{l}\text { Dep. Var. } \\
\text { Model }\end{array}$ & $\begin{array}{c}(1) \\
\text { TOTAL } \\
\text { TOBIT }\end{array}$ & $\begin{array}{c}\text { (2) } \\
\text { TOTAL } \\
\text { OLS }\end{array}$ & $\begin{array}{l}\text { (3) } \\
\text { TERM } \\
\text { TOBIT }\end{array}$ & $\begin{array}{c}(4) \\
\text { TERM } \\
\text { OLS }\end{array}$ & $\begin{array}{c}\text { (5) } \\
\text { WHOLE } \\
\text { TOBIT }\end{array}$ & $\begin{array}{c}\text { (6) } \\
\text { WHOLE } \\
\text { OLS }\end{array}$ \\
\hline SSB & $\begin{array}{c}0.4751 \text { * } \\
(0.1530)\end{array}$ & $\begin{array}{c}0.2163 \\
(0.1621)\end{array}$ & $\begin{array}{c}0.0440 \\
(0.1028)\end{array}$ & $\begin{array}{c}0.0285 \\
(0.0324)\end{array}$ & $\begin{array}{c}1.2214 * \\
(0.3020)\end{array}$ & $\begin{array}{c}0.1680 \\
(0.1433)\end{array}$ \\
\hline PVR & $\begin{array}{c}0.0093 * \\
(0.0019)\end{array}$ & $\begin{array}{l}0.0078 * \star \\
(0.0037)\end{array}$ & $\begin{array}{c}-0.0012 \\
(0.0013)\end{array}$ & $\begin{array}{c}0.0000 \\
(0.0003)\end{array}$ & $\begin{array}{c}0.0122 * \\
(0.0032)\end{array}$ & $\begin{array}{c}0.0068 \\
(0.0035)\end{array}$ \\
\hline Working & $\begin{array}{c}2178.6 \\
(1855.6)\end{array}$ & $\begin{array}{c}1363.0 \\
(1427.4)\end{array}$ & $\begin{array}{l}-147.37 \\
(1250.3)\end{array}$ & $\begin{array}{l}-114.88 \\
(446.70)\end{array}$ & $\begin{array}{c}3936.3 \\
(3527.2)\end{array}$ & $\begin{array}{c}1155.5 \\
(1315.2)\end{array}$ \\
\hline Age & $\begin{array}{r}-441.40 * \\
(78.97)\end{array}$ & $\begin{array}{l}-99.683 * \star \\
(49.534)\end{array}$ & $\begin{array}{c}-310.39 \star \\
(52.850)\end{array}$ & $\begin{array}{r}-80.387 \star \\
(19.030)\end{array}$ & $\begin{array}{c}-448.34 \star \\
(162.02)\end{array}$ & $\begin{array}{r}-16.375 \\
(43.593)\end{array}$ \\
\hline Female & $\begin{array}{r}-8181.7 \star \\
(1366.8)\end{array}$ & $\begin{array}{c}-4836.5 \star \\
(1056.9)\end{array}$ & $\begin{array}{c}-3257.7 * \\
(917.73)\end{array}$ & $\begin{array}{c}-1898.3 * \\
(532.95)\end{array}$ & $\begin{array}{r}-12538.7 * \\
(2635.1)\end{array}$ & $\begin{array}{c}-2738.1 \text { * } \\
(837.44)\end{array}$ \\
\hline Nonwhite & $\begin{array}{c}1640.2 \\
(1302.9)\end{array}$ & $\begin{array}{c}644.77 \\
(619.89)\end{array}$ & $\begin{array}{c}1184.1 \\
(848.02)\end{array}$ & $\begin{array}{c}167.22 \\
(245.36)\end{array}$ & $\begin{array}{l}-3500.7 \\
(2778.8)\end{array}$ & $\begin{array}{c}140.78 \\
(521.08)\end{array}$ \\
\hline Kids & $\begin{array}{l}3078.4 * \star \\
(1401.5)\end{array}$ & $\begin{array}{c}653.55 \\
(685.74)\end{array}$ & $\begin{array}{c}1616.1 \\
(932.16)\end{array}$ & $\begin{array}{c}311.77 \\
(309.70)\end{array}$ & $\begin{array}{c}3076.3 \\
(2858.7)\end{array}$ & $\begin{array}{c}158.92 \\
(565.06)\end{array}$ \\
\hline No. Obs. & 2605 & 2605 & 2738 & 2738 & 2811 & 2811 \\
\hline
\end{tabular}

Notes: Standard errors in parentheses (OLS std. errors are White corrected) * Denotes significance at .01 level

** Denotes significance at .05 level

Specifications also include indicator variables for occupation and education. 
Table 4

Tobit \& OLS Results for Male Widowers Only

\begin{tabular}{|c|c|c|c|c|c|c|}
\hline $\begin{array}{l}\text { Dep. Var. } \\
\text { Model }\end{array}$ & $\begin{array}{c}(1) \\
\text { TOTAL } \\
\text { TOBIT }\end{array}$ & $\begin{array}{c}\text { (2) } \\
\text { TOTAL } \\
\text { OLS }\end{array}$ & $\begin{array}{l}\text { (3) } \\
\text { TERM } \\
\text { TOBIT }\end{array}$ & $\begin{array}{c}\text { ( } 4 \text { ) } \\
\text { TERM } \\
\text { OLS }\end{array}$ & $\begin{array}{c}\text { (5) } \\
\text { WHOLE } \\
\text { TOBIT }\end{array}$ & $\begin{array}{c}\text { (6) } \\
\text { WHOLE } \\
\text { OLS }\end{array}$ \\
\hline SSB & $\begin{array}{c}1.1216 * \\
(0.4331)\end{array}$ & $\begin{array}{c}0.7016 \\
(0.5906)\end{array}$ & $\begin{array}{c}-0.0905 \\
(0.3289)\end{array}$ & $\begin{array}{c}0.0536 \\
(0.0823)\end{array}$ & $\begin{array}{c}2.4462 * \\
(0.6940)\end{array}$ & $\begin{array}{c}0.6040 \\
(0.5502)\end{array}$ \\
\hline PVR & $\begin{array}{c}0.0159 * \\
(0.0044)\end{array}$ & $\begin{array}{c}0.0136 \\
(0.0092)\end{array}$ & $\begin{array}{c}0.0006 \\
(0.0027)\end{array}$ & $\begin{array}{c}-0.0001 \\
(0.0007)\end{array}$ & $\begin{array}{c}0.0155 \star \\
(0.0060)\end{array}$ & $\begin{array}{c}0.0109 \\
(0.0085)\end{array}$ \\
\hline Working & $\begin{array}{r}-7381.7 \\
(6359.4)\end{array}$ & $\begin{array}{l}-5561.8 \\
(3414.7)\end{array}$ & $\begin{array}{r}-13058 * \star \\
(5232.0)\end{array}$ & $\begin{array}{c}-4333.8 * \star \\
(2107.5)\end{array}$ & $\begin{array}{l}-824.04 \\
(9310.5)\end{array}$ & $\begin{array}{l}-2672.8 \\
(2982.9)\end{array}$ \\
\hline Age & $\begin{array}{c}-612.18 \star \star \\
(265.73)\end{array}$ & $\begin{array}{r}-186.26 \\
(228.62)\end{array}$ & $\begin{array}{r}-727.18 * \\
(204.82)\end{array}$ & $\begin{array}{r}-242.08 * \\
(82.403)\end{array}$ & $\begin{array}{r}-290.26 \\
(417.16)\end{array}$ & $\begin{array}{c}58.199 \\
(195.12)\end{array}$ \\
\hline Nonwhite & $\begin{array}{l}-2853.6 \\
(4496.5)\end{array}$ & $\begin{array}{l}-495.99 \\
(1382.7)\end{array}$ & $\begin{array}{l}-3212.2 \\
(3319.4)\end{array}$ & $\begin{array}{r}-1170.1 \\
(780.10)\end{array}$ & $\begin{array}{l}-12367 \\
(7414.0)\end{array}$ & $\begin{array}{l}-983.99 \\
(1012.2)\end{array}$ \\
\hline Kids & $\begin{array}{c}8625.4 \\
(4473.3)\end{array}$ & $\begin{array}{c}3201.0 \\
(2460.2)\end{array}$ & $\begin{array}{l}9285.2 * \star \\
(3647.9)\end{array}$ & $\begin{array}{c}1754.8 * \\
(594.73)\end{array}$ & $\begin{array}{r}-2253.6 \\
(6728.3)\end{array}$ & $\begin{array}{l}-13.368 \\
(2357.1)\end{array}$ \\
\hline No. Obs. & 453 & 453 & 472 & 472 & 487 & 487 \\
\hline
\end{tabular}

Notes: Standard errors in parentheses (OLS std. errors are White corrected)

* Denotes significance at .01 level

** Denotes significance at .05 level

Specifications also include indicator variables for occupation and education. 
Table 5

Tobit \& OLS Results for Female Widows Only

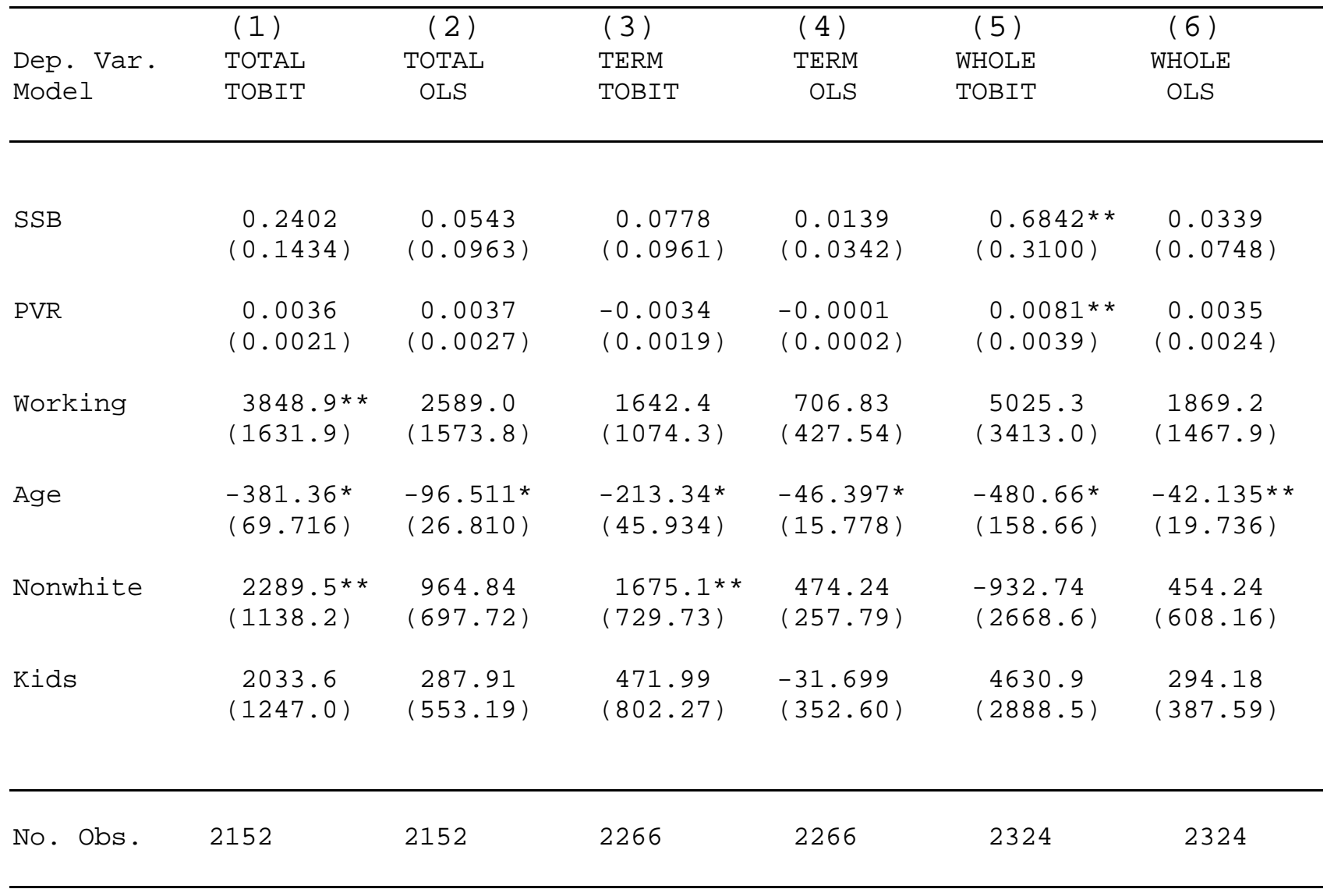

Notes: Standard errors in parentheses (OLS std. errors are White corrected)

* Denotes significance at .01 level

** Denotes significance at .05 level

Specifications also include indicator variables for occupation and education. 
Table 6

Tobit \& OLS Results for Married Couples

Total Household Coverage

\begin{tabular}{|c|c|c|c|c|c|c|}
\hline $\begin{array}{l}\text { Dep. Var. } \\
\text { Model }\end{array}$ & $\begin{array}{c}(1) \\
\text { TOTAL } \\
\text { TOBIT }\end{array}$ & $\begin{array}{c}(2) \\
\text { TOTAL } \\
\text { OLS }\end{array}$ & $\begin{array}{l}\text { (3) } \\
\text { TERM } \\
\text { TOBIT }\end{array}$ & $\begin{array}{c}(4) \\
\text { TERM } \\
\text { OLS }\end{array}$ & $\begin{array}{c}\text { (5) } \\
\text { WHOLE } \\
\text { TOBIT }\end{array}$ & $\begin{array}{c}\text { (6) } \\
\text { WHOLE } \\
\text { OLS }\end{array}$ \\
\hline SSB & $\begin{array}{c}0.9087 \star \\
(0.3225)\end{array}$ & $\begin{array}{c}0.5744 \\
(0.3768)\end{array}$ & $\begin{array}{c}0.2668 \\
(0.1644)\end{array}$ & $\begin{array}{c}0.1036 \\
(0.1459)\end{array}$ & $\begin{array}{c}1.4557 \star \\
(0.4526)\end{array}$ & $\begin{array}{c}0.4745 \\
(0.2910)\end{array}$ \\
\hline PVR & $\begin{array}{c}0.0289 * \\
(0.0038)\end{array}$ & $\begin{array}{c}0.0255 * \\
(0.0082)\end{array}$ & $\begin{array}{c}0.0001 \\
(0.0017)\end{array}$ & $\begin{array}{c}0.0014 \\
(0.0013)\end{array}$ & $\begin{array}{c}0.0327 * \\
(0.0051)\end{array}$ & $\begin{array}{c}0.0209 * \\
(0.0071)\end{array}$ \\
\hline $\begin{array}{l}\text { Working } \\
\text { Husband }\end{array}$ & $\begin{array}{c}6502.8 \\
(4646.6)\end{array}$ & $\begin{array}{c}6889.3 \\
(4739.7)\end{array}$ & $\begin{array}{r}-1602.4 \\
(2468.6)\end{array}$ & $\begin{array}{c}956.93 \\
(1583.4)\end{array}$ & $\begin{array}{c}9439.2 \\
(6478.5)\end{array}$ & $\begin{array}{c}4744.8 \\
(4016.6)\end{array}$ \\
\hline $\begin{array}{l}\text { Working } \\
\text { Wife }\end{array}$ & $\begin{array}{c}9676.4 \\
(5537.6)\end{array}$ & $\begin{array}{c}6512.9 \\
(7429.9)\end{array}$ & $\begin{array}{l}5635.4 \star \star \\
(2868.0)\end{array}$ & $\begin{array}{c}2984.2 \\
(1922.0)\end{array}$ & $\begin{array}{c}2217.8 \\
(7905.2)\end{array}$ & $\begin{array}{c}3270.9 \\
(6234.8)\end{array}$ \\
\hline $\begin{array}{l}\text { Age of } \\
\text { Husband }\end{array}$ & $\begin{array}{c}-1035.9 * \\
(349.25)\end{array}$ & $\begin{array}{l}-294.27 \\
(249.98)\end{array}$ & $\begin{array}{r}-750.98 * \\
(180.27)\end{array}$ & $\begin{array}{c}-284.04 * \\
(76.812)\end{array}$ & $\begin{array}{l}-559.88 \\
(528.26)\end{array}$ & $\begin{array}{c}5.7910 \\
(217.85)\end{array}$ \\
\hline $\begin{array}{r}\text { Age of } \\
\text { Wife }\end{array}$ & $\begin{array}{l}-257.55 \\
(312.22)\end{array}$ & $\begin{array}{l}-309.40 \\
(295.41)\end{array}$ & $\begin{array}{c}66.711 \\
(162.37)\end{array}$ & $\begin{array}{c}-10.409 \\
(79.747)\end{array}$ & $\begin{array}{r}-501.19 \\
(467.29)\end{array}$ & $\begin{array}{l}-277.42 \\
(268.06)\end{array}$ \\
\hline Nonwhite & $\begin{array}{r}-7728.8 \\
(5774.9)\end{array}$ & $\begin{array}{l}-3864.2 \star \star \\
(1758.1)\end{array}$ & $\begin{array}{c}1244.8 \\
(2868.3)\end{array}$ & $\begin{array}{c}-269.17 \\
(715.50)\end{array}$ & $\begin{array}{c}-50519 * \\
(10364)\end{array}$ & $\begin{array}{r}-4134.2 \star \\
(1378.5)\end{array}$ \\
\hline Kids & $\begin{array}{c}7910.6 \\
(5976.5)\end{array}$ & $\begin{array}{c}6200.2 * \\
(2268.0)\end{array}$ & $\begin{array}{c}1091.7 \\
(3128.3)\end{array}$ & $\begin{array}{c}819.06 \\
(1033.0)\end{array}$ & $\begin{array}{c}7681.5 \\
(8835.8)\end{array}$ & $\begin{array}{r}5065.3 * \\
(1848.8)\end{array}$ \\
\hline No. Obs. & 1751 & 1751 & 1893 & 1893 & 1937 & 1937 \\
\hline
\end{tabular}

Notes: $\quad$ Standard errors in parentheses (OLS std. errors are White corrected)

* Denotes significance at .01 level

* Denotes significance at .05 level

Specifications also include indicator variables for occupation and education. 
Table 7

Tobit \& OLS Results for Married Couples

Total Household Coverage

Non-Working Sample Only

\begin{tabular}{|c|c|c|c|c|c|c|}
\hline $\begin{array}{l}\text { Dep. Var. } \\
\text { Model }\end{array}$ & $\begin{array}{l}(1) \\
\text { TOTAL } \\
\text { TOBIT }\end{array}$ & $\begin{array}{c}(2) \\
\text { TOTAL } \\
\text { OLS }\end{array}$ & $\begin{array}{l}(3) \\
\text { TERM } \\
\text { TOBIT }\end{array}$ & $\begin{array}{c}\text { (4) } \\
\text { TERM } \\
\text { OLS }\end{array}$ & $\begin{array}{c}\text { (5) } \\
\text { WHOLE } \\
\text { TOBIT }\end{array}$ & $\begin{array}{c}\text { (6) } \\
\text { WHOLE } \\
\text { OLS }\end{array}$ \\
\hline SSB & $\begin{array}{c}0.0514 \\
(0.3146)\end{array}$ & $\begin{array}{c}-0.1214 \\
(0.3152)\end{array}$ & $\begin{array}{c}0.0850 \\
(0.1722)\end{array}$ & $\begin{array}{c}-0.0426 \\
(0.1103)\end{array}$ & $\begin{array}{c}0.4301 \\
(0.4412)\end{array}$ & $\begin{array}{c}-0.0359 \\
(0.2594)\end{array}$ \\
\hline PVR & $\begin{array}{c}0.0245 * \\
(0.0038)\end{array}$ & $\begin{array}{c}0.0216 * \\
(0.0083)\end{array}$ & $\begin{array}{c}0.0001 \\
(0.0023)\end{array}$ & $\begin{array}{c}0.0017 \\
(0.0013)\end{array}$ & $\begin{array}{c}0.0308 * \\
(0.0052)\end{array}$ & $\begin{array}{l}0.0190 * \star \\
(0.0078)\end{array}$ \\
\hline $\begin{array}{l}\text { Age of } \\
\text { Husband }\end{array}$ & $\begin{array}{c}-1029.7 * \\
(331.78)\end{array}$ & $\begin{array}{c}-348.94 \\
(277.59)\end{array}$ & $\begin{array}{r}-704.88 * \\
(184.08)\end{array}$ & $\begin{array}{c}-277.62 \star \\
(76.702)\end{array}$ & $\begin{array}{l}-500.96 \\
(502.45)\end{array}$ & $\begin{array}{r}-1.4535 \\
(249.83)\end{array}$ \\
\hline $\begin{array}{l}\text { Age of } \\
\text { Wife }\end{array}$ & $\begin{array}{l}-481.67 \\
(300.29)\end{array}$ & $\begin{array}{l}-533.43 \\
(284.52)\end{array}$ & $\begin{array}{c}3.0825 \\
(166.94)\end{array}$ & $\begin{array}{r}-36.418 \\
(71.699)\end{array}$ & $\begin{array}{r}-724.23 \\
(451.59)\end{array}$ & $\begin{array}{r}-484.06 \\
(259.29)\end{array}$ \\
\hline Nonwhite & $\begin{array}{l}-10281 \\
(5301.6)\end{array}$ & $\begin{array}{c}-5453.6 * \\
(1773.4)\end{array}$ & $\begin{array}{l}-170.96 \\
(2799.5)\end{array}$ & $\begin{array}{r}-835.96 \\
(732.26)\end{array}$ & $\begin{array}{l}-48199 * \\
(9721.2)\end{array}$ & $\begin{array}{c}-5221.2 * \\
(1389.7)\end{array}$ \\
\hline Kids & $\begin{array}{c}3042.9 \\
(5466.9)\end{array}$ & $\begin{array}{c}3961.5 \\
(2307.3)\end{array}$ & $\begin{array}{l}-1374.8 \\
(3035.8)\end{array}$ & $\begin{array}{r}-317.32 \\
(1148.5)\end{array}$ & $\begin{array}{c}2415.4 \\
(8135.7)\end{array}$ & $\begin{array}{l}3593.9 * \star \\
(1679.1)\end{array}$ \\
\hline No. Obs. & 1393 & 1393 & 1505 & 1505 & 1536 & 1536 \\
\hline
\end{tabular}

Notes: Standard errors in parentheses (OLS std. errors are White corrected) * Denotes significance at .01 level

* Denotes significance at .05 level

Specifications also include indicator variables for occupation and education. 
Table 8

Tobit \& OLS Results for Married Men

\begin{tabular}{|c|c|c|c|c|c|c|}
\hline $\begin{array}{l}\text { Dep. Var. } \\
\text { Model }\end{array}$ & $\begin{array}{c}(1) \\
\text { TOTAL } \\
\text { TOBIT }\end{array}$ & $\begin{array}{c}(2) \\
\text { TOTAL } \\
\text { OLS }\end{array}$ & $\begin{array}{l}\text { (3) } \\
\text { TERM } \\
\text { TOBIT }\end{array}$ & $\begin{array}{c}(4) \\
\text { TERM } \\
\text { OLS }\end{array}$ & $\begin{array}{c}\text { (5) } \\
\text { WHOLE } \\
\text { TOBIT }\end{array}$ & $\begin{array}{c}\text { (6) } \\
\text { WHOLE } \\
\text { OLS }\end{array}$ \\
\hline SSB & $\begin{array}{c}0.7851 * \\
(0.2640)\end{array}$ & $\begin{array}{c}0.4080 \\
(0.2674)\end{array}$ & $\begin{array}{c}0.1934 \\
(0.1448)\end{array}$ & $\begin{array}{c}0.0370 \\
(0.0960)\end{array}$ & $\begin{array}{c}1.4209 * \\
(0.4154)\end{array}$ & $\begin{array}{c}0.3889 \\
(0.2221)\end{array}$ \\
\hline PVR & $\begin{array}{c}0.0208 * \\
(0.0031)\end{array}$ & $\begin{array}{c}0.0181 * \\
(0.0061)\end{array}$ & $\begin{array}{l}-0.0006 \\
(0.0016)\end{array}$ & $\begin{array}{c}0.0009 \\
(0.0009)\end{array}$ & $\begin{array}{c}0.0259 * \\
(0.0046)\end{array}$ & $\begin{array}{c}0.0154 * \\
(0.0057)\end{array}$ \\
\hline $\begin{array}{l}\text { Working } \\
\text { Husband }\end{array}$ & $\begin{array}{l}7700.2 * \star \\
(3827.4)\end{array}$ & $\begin{array}{c}7240.7 \\
(4047.6)\end{array}$ & $\begin{array}{c}168.17 \\
(2171.6)\end{array}$ & $\begin{array}{c}1259.7 \\
(1235.7)\end{array}$ & $\begin{array}{c}11689 * \star \\
(5883.0)\end{array}$ & $\begin{array}{c}5092.5 \\
(3582.7)\end{array}$ \\
\hline $\begin{array}{l}\text { Working } \\
\text { Wife }\end{array}$ & $\begin{array}{l}-3929.9 \\
(4593.4)\end{array}$ & $\begin{array}{c}-1769.2 \\
(4318.2)\end{array}$ & $\begin{array}{c}2128.6 \\
(2543.2)\end{array}$ & $\begin{array}{c}975.72 \\
(1197.2)\end{array}$ & $\begin{array}{l}-11394 \\
(7368.1)\end{array}$ & $\begin{array}{r}-2225.4 \\
(3810.9)\end{array}$ \\
\hline $\begin{array}{l}\text { Age of } \\
\text { Husband }\end{array}$ & $\begin{array}{c}-1041.5 * \\
(294.07)\end{array}$ & $\begin{array}{l}-270.94 \\
(210.71)\end{array}$ & $\begin{array}{r}-744.40 \star \\
(161.99)\end{array}$ & $\begin{array}{c}-252.96 * \\
(63.281)\end{array}$ & $\begin{array}{l}-791.92 \\
(492.02)\end{array}$ & $\begin{array}{c}0.8571 \\
(189.65)\end{array}$ \\
\hline $\begin{array}{r}\text { Age of } \\
\text { Wife }\end{array}$ & $\begin{array}{r}-184.67 \\
(260.38)\end{array}$ & $\begin{array}{l}-236.69 \\
(246.53)\end{array}$ & $\begin{array}{c}252.68 \\
(145.05)\end{array}$ & $\begin{array}{c}89.866 \\
(50.504)\end{array}$ & $\begin{array}{r}-547.23 \\
(432.07)\end{array}$ & $\begin{array}{r}-324.11 \\
(229.46)\end{array}$ \\
\hline Nonwhite & $\begin{array}{c}-10877 \star \star \\
(4798.9)\end{array}$ & $\begin{array}{c}-3678.9 * \\
(1236.4)\end{array}$ & $\begin{array}{c}454.91 \\
(2504.2)\end{array}$ & $\begin{array}{l}-568.51 \\
(471.63)\end{array}$ & $\begin{array}{c}-50921 \star \\
(10142)\end{array}$ & $\begin{array}{l}-3155.0 * \\
(1042.6)\end{array}$ \\
\hline Kids & $\begin{array}{c}6575.6 \\
(4997.1)\end{array}$ & $\begin{array}{c}5123.3 * \\
(1676.8)\end{array}$ & $\begin{array}{c}877.24 \\
(2762.8)\end{array}$ & $\begin{array}{c}831.61 \\
(848.74)\end{array}$ & $\begin{array}{c}6074.2 \\
(8231.1)\end{array}$ & $\begin{array}{c}4188.6 * \\
(1402.9)\end{array}$ \\
\hline No. Obs. & 1841 & 1841 & 1946 & 1946 & 1979 & 1979 \\
\hline
\end{tabular}

Notes: Standard errors in parentheses (OLS std. errors are White corrected)

* Denotes significance at .01 level

** Denotes significance at .05 level

Specifications also include indicator variables for occupation and education. 
Table 9

Tobit \& OLS Results for Married Women

\begin{tabular}{|c|c|c|c|c|c|c|}
\hline $\begin{array}{l}\text { Dep. Var. } \\
\text { Model }\end{array}$ & $\begin{array}{c}(1) \\
\text { TOTAL } \\
\text { TOBIT }\end{array}$ & $\begin{array}{c}(2) \\
\text { TOTAL } \\
\text { OLS }\end{array}$ & $\begin{array}{l}\text { (3) } \\
\text { TERM } \\
\text { TOBIT }\end{array}$ & \begin{tabular}{c}
\multicolumn{1}{c}{$(4)$} \\
TERM \\
OLS
\end{tabular} & $\begin{array}{c}\text { (5) } \\
\text { WHOLE } \\
\text { TOBIT }\end{array}$ & $\begin{array}{c}\text { (6) } \\
\text { WHOLE } \\
\text { OLS }\end{array}$ \\
\hline SSB & $\begin{array}{c}0.3202 \\
(0.1687)\end{array}$ & $\begin{array}{c}0.2037 \\
(0.1552)\end{array}$ & $\begin{array}{c}0.0562 \\
(0.1173)\end{array}$ & $\begin{array}{c}0.0619 \\
(0.0654)\end{array}$ & $\begin{array}{l}0.6058 * \star \\
(0.2771)\end{array}$ & $\begin{array}{c}0.1420 \\
(0.1163)\end{array}$ \\
\hline PVR & $\begin{array}{c}0.0045 \star \\
(0.0016)\end{array}$ & $\begin{array}{c}0.0035 \\
(0.0022)\end{array}$ & $\begin{array}{c}0.0000 \\
(0.0013)\end{array}$ & $\begin{array}{c}0.0004 \\
(0.0005)\end{array}$ & $\begin{array}{c}0.0060 * \\
(0.0023)\end{array}$ & $\begin{array}{c}0.0030 \\
(0.0018)\end{array}$ \\
\hline $\begin{array}{l}\text { Working } \\
\text { Husband }\end{array}$ & $\begin{array}{c}1373.4 \\
(2503.8)\end{array}$ & $\begin{array}{c}828.63 \\
(1497.5)\end{array}$ & $\begin{array}{l}-2215.4 \\
(1794.2)\end{array}$ & $\begin{array}{l}-251.48 \\
(683.79)\end{array}$ & $\begin{array}{c}4510.9 \\
(3959.9)\end{array}$ & $\begin{array}{c}973.33 \\
(1229.1)\end{array}$ \\
\hline $\begin{array}{l}\text { Working } \\
\text { Wife }\end{array}$ & $\begin{array}{c}9016.2^{\star} \\
(2896.4)\end{array}$ & $\begin{array}{c}5942.7 \\
(3335.7)\end{array}$ & $\begin{array}{l}4203.2 * \star \\
(1988.4)\end{array}$ & $\begin{array}{c}1730.3 \\
(1038.0)\end{array}$ & $\begin{array}{c}9043.8 \\
(4719.6)\end{array}$ & $\begin{array}{c}3937.9 \\
(2924.3)\end{array}$ \\
\hline $\begin{array}{l}\text { Age of } \\
\text { Husband }\end{array}$ & $\begin{array}{r}-365.95 \\
(188.88)\end{array}$ & $\begin{array}{r}-12.422 \\
(84.895)\end{array}$ & $\begin{array}{r}-237.89 \\
(128.56)\end{array}$ & $\begin{array}{r}-23.745 \\
(31.576)\end{array}$ & $\begin{array}{l}-296.10 \\
(321.91)\end{array}$ & $\begin{array}{c}18.801 \\
(74.479)\end{array}$ \\
\hline $\begin{array}{r}\text { Age of } \\
\text { Wife }\end{array}$ & $\begin{array}{r}-232.24 \\
(170.72)\end{array}$ & $\begin{array}{c}-143.55 \\
(113.04)\end{array}$ & $\begin{array}{l}-160.91 \\
(115.72)\end{array}$ & $\begin{array}{c}-98.718 * \star \\
(46.716)\end{array}$ & $\begin{array}{l}-112.64 \\
(291.01)\end{array}$ & $\begin{array}{r}-33.212 \\
(98.039)\end{array}$ \\
\hline Nonwhite & $\begin{array}{r}-1548.3 \\
(2983.3)\end{array}$ & $\begin{array}{c}-1170.1 \\
(688.73)\end{array}$ & $\begin{array}{c}3330.4 \\
(1898.2)\end{array}$ & $\begin{array}{c}284.84 \\
(378.71)\end{array}$ & $\begin{array}{l}-25548 * \\
(6410.8)\end{array}$ & $\begin{array}{l}-1426.5 \star \\
(516.74)\end{array}$ \\
\hline Kids & $\begin{array}{c}2183.6 \\
(3199.7)\end{array}$ & $\begin{array}{c}1302.6 \\
(865.54)\end{array}$ & $\begin{array}{c}364.61 \\
(2207.3)\end{array}$ & $\begin{array}{c}133.78 \\
(406.76)\end{array}$ & $\begin{array}{l}-1333.0 \\
(5295.1)\end{array}$ & $\begin{array}{c}1012.2 \\
(670.07)\end{array}$ \\
\hline No. Obs. & 1896 & 1896 & 1982 & 1982 & 2008 & 2008 \\
\hline
\end{tabular}

Notes: Standard errors in parentheses (OLS std. errors are White corrected)

* Denotes significance at .01 level

** Denotes significance at .05 level

Specifications also include indicator variables for occupation and education. 
Table 10

Asset Spend-down Versus Life Insurance Ownership

\begin{tabular}{|c|c|c|c|c|c|}
\hline & & $\begin{array}{l}\text { WID } \\
\text { Fracti }\end{array}$ & $\begin{array}{l}\text { WERS } \\
\text { ulatio }\end{array}$ & & \\
\hline & $\begin{array}{l}\text { Own } \\
\text { No }\end{array}$ & $\begin{array}{c}\text { Any LI? } \\
\text { Yes }\end{array}$ & $\begin{array}{l}\text { Own } \\
\text { No }\end{array}$ & $\begin{array}{l}\text { Term } \\
\text { Yes }\end{array}$ & LI? \\
\hline Spend Dor & & & & & \\
\hline No & .383 & .383 & .516 & 5.250 & \\
\hline Yes & .105 & .128 & .157 & $7.07 \varepsilon$ & \\
\hline & & $\begin{array}{l}\text { MAR } \\
\text { Fract }\end{array}$ & $\begin{array}{l}\text { PLES } \\
\text { ulatio }\end{array}$ & & \\
\hline & $\begin{array}{l}\text { Own } \\
\text { No }\end{array}$ & $\begin{array}{c}\text { Any LI? } \\
\text { Yes }\end{array}$ & $\begin{array}{l}\text { Own } \\
\text { No }\end{array}$ & $\begin{array}{l}\text { Term } \\
\text { Yes }\end{array}$ & LI? \\
\hline Spend Doy & & & & & \\
\hline No & .173 & .590 & .389 & 9.371 & \\
\hline Yes & .047 & .190 & .115 & 5.125 & \\
\hline
\end{tabular}


Table 11

Determining Fraction of Sample Subject to Over-Annuitization Due to Bequests

\section{Widows/Widowers}

FULL SAMPLE:

Fraction

Holding Any

Insurance

Fraction

Holding Term

Insurance

Minus Those

Purchasing

Private Annuity

Minus Those

With Private

Pension Annuity

Minus Those

Spending Down

Financial Assets

Minus Those

With Zero

Term Premium

Minus Those

With Term

Premium < . 5

Act. Fair

Minus Those

Naming Spouse

as Beneficiary

Minus Policies

Under $\$ 5000$
$100 \%$

$49.9 \%$

$31.5 \%$

$29.9 \%$

$17.7 \%$

$13.9 \%$

$9.2 \%$

$8.9 \%$

$---\frac{\circ}{\circ}$

$2.0 \%$
$39.3 \%$

$14.5 \%$

$10.7 \%$

$8.6 \%$

$7.7 \%$

$0.8 \%$

Married Men

$100 \%$

$70.7 \%$

$41.6 \%$

$0.5 \%$ 